\title{
CLAUDE SCHOPP, Le Paris de Dumas
}

\section{Lise Sabourin}

\section{OpenEdition \\ Journals}

\section{Édition électronique}

URL : https://journals.openedition.org/studifrancesi/31998

DOI : 10.4000/studifrancesi.31998

ISSN : 2421-5856

\section{Éditeur}

Rosenberg \& Sellier

\section{Édition imprimée}

Date de publication : 1 août 2020

Pagination : 423

ISSN : 0039-2944

\section{Référence électronique}

Lise Sabourin, « CLAUDE SCHOPP, Le Paris de Dumas », Studi Francesi [En ligne], 191 (LXIV | II) | 2020, mis en ligne le 01 septembre 2020, consulté le 18 septembre 2021. URL : http://journals.openedition.org/ studifrancesi/31998; DOI : https://doi.org/10.4000/studifrancesi.31998

Ce document a été généré automatiquement le 18 septembre 2021.

\section{(c) (†)}

Studi Francesi è distribuita con Licenza Creative Commons Attribuzione - Non commerciale - Non opere derivate 4.0 Internazionale. 


\title{
CLAUDE SCHOPP, Le Paris de Dumas
}

\author{
Lise Sabourin
}

\section{RÉFÉRENCE}

CLAUDE SCHOPP, Le Paris de Dumas, Paris, Éditions Alexandrines, 2019, 111 pp.

1 Les éditions Alexandrines donnent une édition revue et augmentée du Paris de Dumas (2015) écrit par Claude Schopp en trois chapitres: «Comment Alexandre Dumas devint parisien» (pp.9-30), «Comment Alexandre Dumas voyagea dans Paris» (pp. 31-71) et «Comment les héros de Dumas battent le pavé de Paris» (pp. 73-91).

2 Cette tripartition revient, pour un écrivain qui à la fois eut tant de fois le plaisir de quitter Paris et le désir d'y revenir, à narrer pratiquement toute son existence, avec ses multiples changements de domiciles, puis à retrouver ses lieux favoris à travers ses personnages, dans Les Trois Mousquetaires un peu, dans Le Comte de Monte Cristo bien davantage, dans Les Mohicans de Paris enfin bien sûr.

3 Les repères biographiques qui suivent (et redoublent un peu), la bibliographie succincte et l'index des lieux cités finissent de faire de ce petit livre bref et alerte un outil d'entrée commode dans l'œuvre et la vie de Dumas pour bien des lecteurs du grand public, qui se laissent porter par l'habituelle liberté d'allure du célèbre auteur. 